IZA DP No. 4226

Foreign Acquisition, Plant Survival, and Employment Growth

Roger Bandick

Holger Görg

June 2009 


\title{
Foreign Acquisition, Plant Survival, and Employment Growth
}

\author{
Roger Bandick \\ Aarhus School of Business \\ Holger Görg \\ Kiel Institute for the World Economy, \\ University of Kiel and IZA
}

\section{Discussion Paper No. 4226 \\ June 2009}

\author{
IZA \\ P.O. Box 7240 \\ 53072 Bonn \\ Germany \\ Phone: +49-228-3894-0 \\ Fax: +49-228-3894-180 \\ E-mail: iza@iza.org
}

\begin{abstract}
Any opinions expressed here are those of the author(s) and not those of IZA. Research published in this series may include views on policy, but the institute itself takes no institutional policy positions.

The Institute for the Study of Labor (IZA) in Bonn is a local and virtual international research center and a place of communication between science, politics and business. IZA is an independent nonprofit organization supported by Deutsche Post Foundation. The center is associated with the University of Bonn and offers a stimulating research environment through its international network, workshops and conferences, data service, project support, research visits and doctoral program. IZA engages in (i) original and internationally competitive research in all fields of labor economics, (ii) development of policy concepts, and (iii) dissemination of research results and concepts to the interested public.
\end{abstract}

IZA Discussion Papers often represent preliminary work and are circulated to encourage discussion. Citation of such a paper should account for its provisional character. A revised version may be available directly from the author. 


\section{ABSTRACT}

\section{Foreign Acquisition, Plant Survival, and Employment Growth*}

This paper analyses the effect of foreign acquisition on survival probability and employment growth of target plant using data on Swedish manufacturing plants during the period 19932002. An improvement over previous studies is that we take into account firm level heterogeneity by separating the targeted plants into those within Swedish MNEs, Swedish exporting non-MNEs, and purely domestic firms before foreign takeover. The results, controlling for possible endogeneity of the acquisition dummy using an IV and propensity score matching approach suggest that acquisition by foreign owners increases the lifetime of the acquired plants only if the plant was an exporter. The effect differs depending on whether the acquisition is horizontal or vertical. We also find robust positive employment growth effects only for exporters, and only if the takeover is vertical, not horizontal.

JEL Classification: F23, L23

Keywords: acquisitions, plant survival, employment growth, multinational enterprises

Corresponding author:

Holger Görg

Universität Kiel

Institut für Volkswirtschaftslehre

Wilhelm-Seelig-Platz 1

D-24118 Kiel

Germany

E-mail: goerg@economics.uni-kiel.de

\footnotetext{
* We are grateful to two anonymous referees and Werner Antweiler for very helpful comments on an earlier draft.
} 


\section{Introduction}

Foreign direct investment (FDI) is one of the main aspects of current day globalization. The total volume of world-wide FDI has increased tremendously in the last two decades. UNCTAD (2007) shows that, in 2006, total FDI flows amounted to 1.3 trillion USD, contributing to a total world-wide FDI stock of roughly 12 trillion USD - equivalent to about 25 percent of world GDP. At the same time it is well known that the majority of FDI flows are due to international mergers and acquisitions (M\&A) rather than setting up new projects abroad (greenfield). Again, UNCTAD (2007) shows that in 2006 the total value of worldwide cross-border M\&As was roughly 0.9 trillion USD, amounting to about 70 percent of total FDI flows. ${ }^{1}$

These trends have brought international mergers into the academic debate, with recent literature attempting to model these activities theoretically and providing empirical evidence on their determinants (e.g., Neary, 2007, Hijzen et al., 2008, Head and Ries, 2008). Moreover, the growing importance of M\&As has given rise to policy concerns as to the impact of such cross-border mergers for domestic economies. From the point of view of the host country, a potential downside is that a foreign multinational acquiring a domestic firm may shut down the plant or part thereof completely after acquisition, or reduce employment. ${ }^{2}$ On the positive side, however, a foreign acquisition may bring new technology and market access opportunities and, thus, strengthen the overall competitiveness and survival prospects of the takeover target.

In this paper we study in detail the implications of foreign acquisitions for the survival and employment growth prospects of the target plants. We investigate firstly plant closures as the adjustment along the extensive margin, as they are an important aspect of industry dynamics, shaping industry productivity and forming the competitive landscape in an economy. ${ }^{3} \mathrm{We}$ also, however, consider the intensive margin of adjustment by examining what happens to

\footnotetext{
${ }^{1}$ Strictly speaking the UNCTAD data on FDI and M\&A are not fully comparable as they come from different sources. Still, they give a good indication of the importance of M\&A.

${ }^{2}$ Recall, for example, the public debate surrounding the Vodafone takeover of the German company Mannesmann in 1999 / 2000: http://www.eurofound.europa.eu/eiro/1999/11/feature/de9911220f.htm (accessed on 7 August 2008).

${ }^{3}$ It is also one aspect of plant outcomes that is still under-researched. By contrast, productivity and wage effects of foreign acquisitions have received far higher attention in the literature. See, for example, papers by Arnold and Javorcik (2005), Girma and Görg (2007a,b), Harris and Robinson (2002), Petkova (2007), Fukao et al. (2006). A related literature also considers the effect of changes in managerial ownership and firm performance, e.g., Harris et al. (2005) and Coles et al. (2007).
} 
employment growth in surviving firms after acquisitions. We use recent unique detailed plant level data (which also provide some information at the firm level) for Sweden to investigate survival probabilities in the context of a hazard model. We take particular account of the potential endogeneity of the acquisition decision (for example due to "cherry picking") by implementing an instrumental variables approach. Furthermore, we check the robustness of the IV approach with estimations on a matched sample of firms based on propensity score matching.

Sweden is an interesting case to analyze in this context. Over the last two decades Sweden has introduced a considerable amount of liberalization reforms in order to promote foreign ownership. However, it was not until 1995, that in connection with Swedish membership in the European Union (EU) the business climate improved considerably and Swedish firms became more attractive targets for foreign investors. Ever since then, Sweden has witnessed a rapid increase of inward FDI, mainly through mergers and acquisitions. Well-known former Swedish owned multinational enterprises, such as Astra, Pharmacia, Volvo Car and Saab Automobile, changed ownership in the 1990s and are now foreign owned. At the beginning of the 2000s, the employment share in foreign owned firms in manufacturing was among the highest in OECD. ${ }^{4}$

The empirical evidence on the impact of foreign acquisitions on survival probabilities is rather limited. A few studies, e.g. Bernard and Sjöholm (2003) for Indonesia, and van Beveren (2007) for Belgium document differences in survival rates between foreign multinationals and domestic plants (the latter paper distinguishing domestic multinationals from purely domestic plants). ${ }^{5}$ These studies indicate that the probability of shutdown is larger for plants that are part of a multinational, at least when controlling for other factors related to plant survival. As to studying the effect of a foreign acquisition on survival, one of the few papers to have looked at this is Girma and Görg (2004). They find evidence that foreign acquisition reduces the lifetime of acquired UK plants in electronics and food industries.

\footnotetext{
4 As compared to 21 other OECD countries in 2002, only Ireland, Luxembourg and Hungary had larger employment shares than Sweden in foreign owned firms in manufacturing (Hansson et.al. 2007).

${ }^{5}$ Another related study is by Bernard and Jensen (2007) who focus on differences in plant survival rates in US manufacturing between plants within domestic US multinationals and other plants. They do not distinguish the takeover by a foreign firm.
} 
There is a somewhat richer literature on employment effects of acquisition, but this is by no means exhaustive. For example, Conyon et al (2002) using firm level data for the UK find that labour demand of the typical firm decreased somewhat in the years following foreign acquisition. Huttunen (2007) and Almeida (2007) using data for Finland and Portugal respectively, focus on employment by skill groups. Huttunen finds that foreign acquisition decreases the share of high skilled workers in targets, while Almeida finds no significant effects on relative employment of skills in Portugal.

We extend and improve upon these earlier papers in a number of ways. First, we examine acquisitions by foreign multinationals and use different econometric approaches to be able to identify the causal effect of takeovers on exit probability and employment growth changes of a plant. Second, using the detailed and unique data for Sweden we are able to link our empirical work to the recent literature on firm heterogeneity in international trade (e.g, Helpman et al., 2004). Specifically, we are able to categorize all domestic firms into being either (i) a domestic firm with affiliates abroad, (ii) a domestic firm with export sales (and no foreign affiliates) and (iii) a purely domestic firm with no involvement on foreign markets. We refer to (i) and (ii) as domestic multinationals and domestic exporters, respectively, in what follows. Theoretical heterogeneous firm models would predict that these types of plants are intrinsically different. We therefore analyse whether the extent of global engagement of the plant (multinational, exporting, none) impacts on plant survival through mediating the impact of foreign acquisition on the target.

The quality of our data also allows further novelties in our research design. Firstly, we can use our data to identify domestic acquisitions. This allows us to investigate whether our foreign acquisition effect merely reflects a "pure acquisition effect" that would be similar for domestic acquisitions also, or whether there is a particular "foreign effect". Due to data limitations, not many studies that have investigated foreign acquisitions have been able to take this into account. Secondly, we investigate whether the effect of acquisitions is different depending on whether the acquisition is horizontal or vertical. This has, to the best of our knowledge, not been investigated in earlier studies. ${ }^{6}$ Finally, our data combines plant level with firm level information and is therefore able to control for the role of firm attributes for

\footnotetext{
${ }^{6}$ Moreover, unlike some of the earlier studies, our data allows us to be confident that we observe true exits in our data set; these are not due to plants disappearing from the data due to mergers and acquisitions or because they drop in size below a certain cut-off level. The former is a potential issue in Mata and Portugal (2002), while the latter problem potentially affects the study by Van Beveren (2007).
} 
plant survival. Bernard and Jensen (2007) is one of the few other papers in the literature that are able to do so. They include a dummy for plants that are part of a multiplant firm. We do not only this but are also able to investigate whether plants probability of exit is influenced by whether or not other plants within the same firm failed in the same period.

To preview our results, we find, after controlling for the possible endogeneity of the acquisition dummy and also controlling for a number of plant and firm specific characteristics, that foreign acquisition has an effect on plant survival only for domestic exporters. Depending on whether the acquisition is horizontal (i.e., within the same industry) or vertical, acquired exporters have 20 to 30, or 6 to 8 percent higher survival probabilities, respectively, compared to plants of non-acquired firms. We also find that employment growth is higher in takeover targets that were exporters prior to acquisition.

The remainder of the paper is structured as follows. Section 2 discusses some background to motivate our empirical analysis. Section 3 presents the data and illustrates the increased importance of foreign ownership in Swedish manufacturing in the 1990s. Section 4 discusses the analytical framework and empirical results for the effect of foreign acquisitions on plant survival, while Section 5 focuses on employment growth effects. Section 6 concludes.

\section{Theoretical and empirical motivation}

Conceptually, the effect of a foreign acquisition on the survival and employment growth prospects in the target plant are not unambiguous. In the standard models of multinationals, these types of firms are generally assumed to have some sort of firm specific asset or efficiency advantage that enables them to operate abroad successfully (Markusen, 2002; Helpman, Melitz, Yeaple, 2003). If a foreign multinational then takes over a domestic plant, it may be likely that some of the firm specific asset is transferred to the takeover target in terms of technology, know-how, skills, etc.. This, in turn, may increase survival prospects and raise employment growth (and other aspects of firm performance) in the acquired target. One may call this a benevolent view of the actions of the acquirer.

A different view may be that multinationals, due to their advantages, may use foreign acquisitions in order to gain market access and eliminate competition by taking over a rival and closing it down afterwards, or reducing substantially the scale of operations and therefore 
reducing employment (e.g., Thompson, 1999). In this case, the expected effects of a foreign acquisition on survival and growth would clearly be negative.

An argument with similar predicted outcomes can be constructed around the empirical observation that foreign owned multinationals are generally more "footloose" than domestic firms in the host country (e.g., Bernard and Sjöholm, 2003). This is attributed to their possibilities of relocating production and employment among their affiliates in different countries and, hence, their ability to respond more quickly to changes in the business environment in alternative host countries. If this is the case, then the change in ownership may lead to lower survival probabilities and employment growth in the takeover target, as the multinational owner may be quicker to shut down or reduce employment in the plant once it is part of the multinational firm structure.

The effects of foreign acquisitions may still be ambiguous a priori even when distinguishing acquisitions motivated by either horizontal or vertical motives. For the former, firms acquire plants abroad in order to gain market access. If the aim of the market access is to eliminate competition and consolidate the industry, then it is likely that it may lead to plan closures and plant downsizing. On the other hand, the acquisition may be designed to open new markets by using the already existing facilities owned by other firms in the foreign markets, i.e., the acquirer intends to "grow by acquisition". Then the acquirer is likely to maintain the plant network that is already available, and improve them through technology transfers in order to suit its own needs. In this case, the prospects for the acquired target would be positive in terms of both survival and employment growth.

This may be different for non-horizontal, in particular vertical acquisitions. If the motive is to acquire plants at different stages of the production process, then it is likely that this is done with a view to integrating these into the multinational company structure. In this case, the acquirer may transfer technology and improve quality in the acquisition target, leading to improvements in survival and employment prospects.

For acquisitions that are not related through input-output linkages or horizontal motives, foreign acquirers may use the acquisition as a device to acquire access to the country, technology, skills, etc. through the acquisition, even if it is not immediately linked into the production process. Once these resources have been ingested the acquiring firm may divest 
itself of the acquired establishment, and source its requirements from its plants elsewhere (Thompson, 1999). Hence, in this case, there would be clear negative effects on survival probabilities in the takeover target after foreign acquisition.

Another consideration when formulating expectations concerning the post acquisition effects relates to the characteristics of the acquisition target. Since plants of globally engaged firms tend to be a priori "better" along a line of observable and (to the econometrician) unobservable characteristics they may be able to experience different effects if they are acquired. As established in the recent literature on heterogeneous firms in international trade, there is theoretical justification and empirical evidence for the findings that multinationals tend to be the most productive firms, followed by exporters who are not multinationals, and that firms without any foreign involvement are the least productive. This may have implications for their post acquisition expectations.

In particular, "better” targets are likely to be able to absorb technology transfers from the foreign acquirer more easily. However, since plants of domestic multinationals are already at a similar level of technology as foreign multinationals (Criscuolo and Martin, 2008) we may not expect that foreign acquisition improve their survival prospects or employment growth. Furthermore, since domestic multinationals are already highly footloose (similar to foreign multinationals), we would not necessarily expect that foreign acquisition increases substantially their exit probabilities. Hence, if foreign acquisitions are accompanied by technology transfers, we expect these to be most effective for targets that are exporting plants, but not necessarily in multinational plants, compared to targets in purely domestic firms. This is because the evidence shows that exporters are more productive than purely domestic firms (Wagner, 2007), while domestic multinationals outperform exporters (Greenaway and Kneller, 2007) and are more similar to foreign multinationals (Criscuolo and Martin, 2008). We therefore expect to see larger positive effects of foreign acquisitions on plant survival and employment growth for targets that were already exporters.

\section{A first look at the data}

The data used in this paper are uniquely assembled and combine data from Statistics Sweden (SCB) and the Swedish Institute for Growth Policy Studies (ITPS). The data consist of three 
register-based datasets where information at the plant and firm-level are linked together by a unique identification code. Our period of observation covers 1993 to 2002.

Statistics Sweden provided two datasets, the Regional Labor Market Statistics (RAMS) and Financial Statistics (FC). The former contains information at the plant-level for the population of manufacturing plants on variables such as total employment, the number of employees with post-secondary education, and age of the plant. ${ }^{7}$ Each plant is identified by a unique plant identifier. The appearance of a new identification number implies necessarily that a new plant has entered, the disappearance of a previous number means that this plant has exited. If the number remains unchanged in subsequent years the plant has survived. Furthermore, RAMS reports firm and industry codes for each plant.

The firm code attached to each plant enables us to match data from Financial Statistics (FC) including information at the firm-level such as labour productivity, capital-labour ratio, exports, whether a firm is multi- or single-plant, and ownership status (foreign or domestic). A firm is foreign if foreign owners posses more than 50 percent of the voting rights. Using this data we define a foreign acquisition as a change in the ownership indicator from domestic to foreign. ${ }^{8}$ The firm-level variables are available from the year 1993 and onwards only for larger firms, i.e. firms with 50 employees and more.

The database provided by ITPS is a register of all Swedish firms that are multinational enterprises (MNE). ${ }^{9}$ By merging the three databases using the firm identifier of plants, we can assign the firm level information to the plant level data. In that way we can also separate plants into those within foreign MNEs, plants part of a Swedish MNE, plants part of an exporting (non-MNE) firm and plants that operate purely domestically. A Swedish MNE is defined as a domestically owned firm which is part of an enterprise group with affiliates abroad. In foreign-owned firms, foreigners possess more than 50 percent of the voting rights.

\footnotetext{
${ }^{7}$ We have access to plant-level data from 1986 onwards. For plants entering after 1986 we are able to calculate the exact plant age, while older plants are improperly assigned to enter in 1986.

${ }^{8}$ Plants within firms that switch between domestic and foreign ownership more than once over the period are not included in the sample. Also, plants in firms that disappear from the sample one year and reappear in later years are also excluded.

${ }^{9}$ The first year we can distinguish Swedish MNEs from non-MNEs is 1993 and explains why our analysis begins in 1993.
} 
The clear distinction into different types of MNEs and exporting activities is a distinct advantage of our data over the previous literature. This is an important dimension to the analysis since the prospect of survival and employment growth may differ between ownership structures due to their ex-ante different characteristics as highlighted by, for example, Helpman et al. (2004). Moreover, with our data we can be confident, given that it covers the whole population of plants, that we observe true exits and do not confound them with (i) disappearance of a plant code due to mergers \& acquisitions, or (ii) a plant dropping out of a sample due to size thresholds for inclusion in the sample. ${ }^{10}$ Furthermore, our data covers the 1990s and early 2000s, which is a particularly interesting period to study given recent increases in international merger activity.

During the 1990s, Sweden went through a period of liberalization reforms in order to promote foreign ownership. Since then, foreign ownership increased rapidly and the trend seems to have been more pronounced in Sweden than in other OECD countries (see Hansson et al., 2007). Table 1 shows that in the 1990s, the employment share in plants within foreign MNEs increased by almost 27 percentage points. This trend seems to have evolved at the expense of Swedish MNEs whose employment share dropped by 21 percentage points. The table also shows that over the period 1993 to 2002, the share of plants within foreign MNEs increased from 26 percent to 41 percent, whereas the share of plants within Swedish MNEs has fallen by almost 7 percentage points. The employment and plant shares for Swedish exporters remained fairly constant over the period, however.

\section{Table 1 here}

During the 1990s several large Swedish multinationals have become foreign-owned due to acquisitions by foreign MNEs, e.g. Pharmacia and Upjohn 1995, Saab Automobile and General Motors 1998, Astra and Zeneca 1999 and Ford and Volvo Car Corporation 1999. Table 2 reports, by year, the frequencies of plant acquisitions by foreign firms. On average 33 percent of plants acquired were part of Swedish MNEs before foreign takeover, and almost 58 percent were plants of Swedish exporters. Table 2 also shows that more than 90 percent of

\footnotetext{
${ }^{10}$ Our data, due to the restrictions of the FC database, only include firms with 50 employees or more. However, since we use plant-level data for the population of plants from RAMS we still can observe all the plants that are within a firm, even if that firm drops below the threshold size value. Hence, contrary to some papers in the literature, we do not mix sample exit with true exit.
} 
the employees in the takeover targets were employed in plants part of Swedish MNEs or Swedish exporters before foreign acquisition. ${ }^{11}$

Table 2 here

Table 3 shows that in the years before acquisition, plants within acquired firms are larger in terms of employment and are younger than plants of non-acquired firms. Moreover, the acquired firms seem to have higher skill and R\&D intensity, higher labour productivity and capital-labour ratios and are more export intensive than non-acquired firms in the preacquisition years. Table 3 also provides us with some evidence of "cherry picking”, i.e. that firms that perform "well” and have plants with "good" characteristics are more likely to be acquired by foreigners.

Table 3 here

Differences in characteristics and performance between acquired and non-acquired plants in the years before acquisition could bias the estimates of the causal effect of foreign acquisition on plant survival or employment growth. To overcome this problem, we use various econometric methods, which we discuss in detail in the following sections. We examine firstly the impact of foreign acquisition on plant survival, i.e., adjustment after acquisition along the extensive margin.

\section{Foreign acquisition and plant survival}

\subsection{Methodology}

To establish whether the acquisition of a plant by foreign owners changes its survival prospects compared to other plants we model the determinants of plant survival and check whether the incidence of acquisition is a statistically significant determinant of a plant's hazard of exiting. We use a complementary log-log model (cloglog) for the empirical estimations. ${ }^{12}$ The underlying assumption of the proportional hazard model is that the hazard

\footnotetext{
${ }^{11}$ In the appendix in Table A1 we show the distribution of acquisitions by plant and firm across manufacturing sectors. Over the period studied, 12 percent of all manufacturing firms were acquired by foreign firms (Recall that firm level information is only available for firms with 50 or more employees.) Over the same period, 7 percent of all plants were acquired. Moreover, the shares of foreign acquisitions are more pronounced in sectors with a high degree of product differentiation and high $\mathrm{R} \& \mathrm{D}$ intensity such as chemicals, metals and motor vehicles.

12 The related empirical IO literature (e.g., Audretsch and Mahmood, 1995, Disney et al., 2003) generally uses a Cox proportional hazard model for this type of analysis. Given that our data are collected on a yearly basis, the
} 
ratio depends only on time at risk, $\theta_{0}(t)$ (the so-called baseline hazard) and on explanatory variables affecting the hazard independently of time, $\exp \left(\beta^{\prime} X\right)$. The hazard ratio is then given by:

$$
\theta(t, X)=\theta_{0}(t) \exp \left(\beta^{\prime} X\right)
$$

More specifically, the discrete-time hazard function takes the following form:

$$
h(j, X)=1-\exp \left[-\exp \left(\beta^{\prime} X+\gamma_{j}\right)\right]
$$

where $h(j, X)$ shows the interval hazard for the period between the beginning and the end of the $j^{\text {th }}$ year after the first appearance of the plant and $\gamma_{j}=\log \int_{a_{j-1}}^{a_{j}} \theta_{0}(t) d t$ capture, within each interval, period specific effects on the hazard. The $\beta$ parameters show the effects of the explanatory variables $X$ (at the plant and firm level) on the hazard rate. ${ }^{13}$

The main interest in our analysis is a dummy variable showing whether a plant is part of a Swedish firm that has been acquired by a foreign MNE (Foreign Acquired). The dummy switches to one in the year that the firm changes its ownership status from domestic to foreign, and is zero if ownership status is domestic.

To be able to identify the acquisition effect we need to control for other plant level variables that are potentially correlated with it and that also affect plant survival. The literature generally finds that plant size and age are important determinants of plant survival. We, therefore, include both variables in the vector $X$. Size is measured as log employment size and plant age as years of operations. Furthermore, we calculate a measure of skill intensity of a plant's production process. This is defined as the percentage of employees with postsecondary education in a plant relative to the industry mean skill intensity.

cloglog model is more appropriate. Essentially, it is equivalent to the discrete time version of the proportional hazard model. The cloglog model has the same assumptions on the coefficient vector $\beta$ as the continuous-time version of the proportional hazard model (Prentice and Gloeckler, 1978).

${ }^{13}$ The cloglog model does not allow for unobserved plant heterogeneity. To do so we use the random-effects version of complementary log-log model as a robustness check. As these estimations produce results that are largely comparable with the simple cloglog model, we only report in the Appendix (Table A4) estimations of the preferred specifications using this alternative estimator, to save space. 
We also take into account variables at the firm level. We include a dummy capturing whether or not a firm is a multi-plant operation. This has been shown by Bernard and Jensen (2007) as an important determinant of firm survival. We also go further than this and check whether restructuring within the firm affects plant survival. To do so, we calculate a dummy variable that is equal to one if another plant in the same firm exited, either as a result of the foreign acquisition or due to other reasons. Furthermore, we control for R\&D intensity, capital intensity, and labor productivity at the firm level.

The final baseline hazard model can then be written as:

$h(j, X)=1-\exp \left[-\exp \left(\beta_{0}+\beta_{1}\right.\right.$ Acquired $+\beta_{2}$ plant_controls $+\beta_{3}$ firm_controls $\left.\left.+\gamma_{j}\right)\right]$

We expand on this baseline model in the empirical analysis in a number of ways. First, we include a dummy variable for domestic acquisitions in order to identify whether the variable captures a general acquisition effect or some specifically foreign effect. Second, we allow the effects of foreign acquisitions to differ for horizontal and vertical acquisitions (the definitions of these are discussed below). Third, we allow the acquisition effect to differ across plants depending on whether they are within globally engaged firms, i.e. Swedish MNEs and exporting non-MNEs, or purely domestic firms before foreign takeover. This accounts for an important aspect of firm heterogeneity highlighted in the recent theoretical and empirical literature, namely, that there is a clear ordering of firm types, with the "best" becoming outward investors, the next exporters, and the least equipped firms remaining in the domestic market (Helpman, et al., 2004). This can have implications for the post-acquisition survival prospects.

In Table 4 we calculate simple Kaplan-Meier survival functions to compare survival probabilities of the three different types of firms. As the table shows, Swedish multinationals have the lowest survival probabilities, i.e., they are the most footloose of the type. This is in line with the empirical finding that foreign multinationals have higher exit probabilities than purely domestic firms (e.g., Bernard and Sjöholm, 2003) - i.e., domestic multinationals are 
similar to foreign multinationals in this respect. ${ }^{14}$ By contrast, there is no clear difference in survival probabilities between purely domestic plants and exporters; the functions cross at time $\mathrm{t}=3$.

\section{Table 4 here}

Before proceeding to the estimation results we need to describe in more detail our identification strategy. In equation (3) identification of the coefficient $\beta_{1}$ on the acquisition dummy rests on the assumption that, conditional on the plant and firm controls included, acquisition is exogenous. This is, arguably, a strong assumption. If it does not hold, then the stochastic dependence between the acquisition dummy and the error term may bias our estimates. In order to take account of this possible endogeneity we use two approaches: instrumental variables estimation and selection of a control group based on propensity score matching.

For the first approach we construct an instrumental variable as the probability of a firm being taken over by foreign owners. This instrumental variable is calculated as the predicted value of the dependent variable from a probit regression for the probability of foreign takeover. ${ }^{15}$ The probit model is

$$
p\left(\text { Acquisition }_{i t}=1\right)=F\left(X_{i t-1}, D_{j}, D_{t}\right)
$$

where $X$ is a vector of firm and plant characteristics in $t-1$. This vector includes, in the first instance, labor productivity in firm $i$, plant age, age-squared, current employment size (relative to the industry mean), R\&D and skill intensity, export intensity, and a measure of foreign presence in the industry. The latter measure captures potential spillover effects in an industry. $D_{j}$ and $D_{t}$ control for fixed industry and time effects. In a robustness check we

\footnotetext{
14 This mirrors recent contributions to the literature on productivity differences between multinationals and domestic firms which show that it is multinationality per se, and not foreign ownership, which is correlated with a productivity premium vis-a-vis domestic firms. In other words, domestic and foreign multinationals are more productive than purely domestic firms. See, for example, Criscuolo and Martin (2008) using UK data.

${ }^{15}$ A similar approach was taken by McGuckin and Nguyen (2001) who analyse the effect of acquisitions on plant exit in the US, and Hujer et al. (1999) in a nonlinear hazard model for the analysis of the effect of training on unemployment duration in Germany. Conyon et al. (2002) also use this approach in modelling the wage effects of foreign acquisitions. Note that, in order to get accurate standard errors for the estimators using generated IV we compute bootstrapped standard errors.
} 
also investigate how robust results are to changes in the variables that are included in the probit.

The results of estimating equation (4) are reported in Table 5. The estimation results suggest that more productive, skill intensive and export oriented plants are more likely to be acquired. Furthermore, firms located in industries with higher foreign presence are more likely to become acquisition targets. We also estimated alternative specifications of equation (4), including additional variables in the probit estimation, to check whether our results depend on the process by which the instrument was generated. These results are reported on columns (ii) and (iii) of the table. The estimation of the hazard models below is robust to this change in the instrument generating specification.

\section{Table 5 here}

In an alternative approach we use propensity score matching to establish a valid counterfactual of non-acquired firms which have similar pre-acquisition characteristics to the acquired firms. Under the matching assumption, conditional on the propensity score, acquisition is random. We then carefully construct a sample of acquired plants and matched non-acquired plants, and estimate equation (3) on this matched sample. ${ }^{16}$

The idea of the propensity score matching method is to find, for every foreign acquired firm, a similar firm that has remained in domestic hands and from which we can approximate the non-observed counterfactual event. Thus, the matching technique enables us to construct a sample of acquired and non-acquired firms with similar pre-acquisition characteristics $X$, e.g. productivity, wages, size etc. Conditional on these characteristics we estimate the probability (or propensity score) of being acquired by a foreign firm using the same probit model as in equation (4).

Once the propensity scores are calculated, we can (using the "caliper" matching method) select the nearest control firms in which the propensity score falls within a pre-specified

\footnotetext{
${ }^{16}$ A similar approach of using matching to establish a control group was employed by Greenaway and Kneller (2008). See also Arnold and Javorcik (2005), Girma and Görg (2007a) and Petkova (2007) for recent applications of propensity score matching, and descriptions of the assumptions and tests, in the context of identifying the effects of foreign acquisitions on target firms.
} 
radius as a match for an acquired firm. ${ }^{17}$ Moreover, we check whether the balancing condition is verified, that is each independent variable do not differ significantly between acquired and non-acquired firms.

Another condition that must be fulfilled in the matching procedure is the so-called common support condition. This criterion implies that at each point in time, a newly acquired firm is matched with non-acquired firms with propensity scores only slightly larger or smaller than the target firm. Note that some acquired firms may be matched with more than one nonacquired firm, while acquired firms not matched with a non-acquired firm are excluded. Eventually, we end up with a sample, henceforth denoted the matched sample, which consists of 207 acquired firms with 907 plants and 2,372 non-acquired firms with 10,776 plants.

Since the aim of the matching is to find a group of acquired and non-acquired firms with similar characteristics we once more report, in the appendix in Table A2, mean variable differences between the two groups of firms that were successfully matched together. The matching procedure has substantially reduced the firm-level differences between acquired and non-acquired firms. Regarding the plant-level characteristics, the differences are slightly reduced as compared to the unmatched sample in Table 3. However, there still are significant differences between plants of acquired firms and plants of non-acquired firms. Hence, in the estimation of the hazard model we control for variations among the plants with respect to size, age and skill intensities. Finally, from Table A3 in the appendix it is clear that the matching procedure also has been successful in constructing a sample with the same structure of ownership changes as in the unmatched sample.

\subsection{Empirical results}

To examine whether survival prospects differ across foreign-acquired and non-acquired plants, we estimate different specifications of the hazard model described in equation (3). We report the hazard ratios (exponentiated coefficients) which allow a straightforward interpretation of the coefficient size. For example, a ratio $\beta$ less than one on a dummy variable implies that changing the dummy from 0 to 1 reduces the hazard rate of exiting (or increases the probability of survival) by $(1-\beta) * 100$ percent, ceteris paribus.

\footnotetext{
${ }^{17}$ The procedure we utilize to match acquired and non-acquired firms is the PSMATCH2 routine in Stata version 10 described in Leuven and Sianesi (2003). In our analysis, the pre-specified radius is set to 0.01 .
} 
Table 6 presents the main estimation results. In the first four columns we report the result from estimating equation (3) for the whole sample, i.e. Swedish manufacturing plants in firms with 50 employees or more between 1993 and 2002. The results in column (i) are based on estimation of the hazard model assuming that foreign acquisitions are exogenous conditional on the control variables. The column reveals that plants of acquired firms are more likely to survive than plants of non-acquired firms. Controlling for plant and firm level characteristics, acquisition by foreign owners increases a plant's probability of survival by roughly 30 percent.

In terms of the control variables it is reassuring to note that their results are largely as expected. In line with the large IO literature on firm survival we find that older, larger and more skill intensive plants have lower exit hazards. We do not find that plants that are part of a multiplant firm per se are more or less likely to exit than other plants. However, we do find evidence that a plant's exit probability is reduced if another plant in the same firm failed. Furthermore, plants in firms with higher labor productivity, and lower capital intensities, are more likely to survive.

Returning to the effect of acquisition on survival, our results thus far suggest that this is positive. However, this may be purely due to foreign acquirers choosing targets with a priori positive characteristics, a practice known as "cherry picking", as illustrated above in Tables 3 and 5. These characteristics may also account for the higher survival probabilities of such plants after acquisition. To some extent, this is already accounted for by the large number of relevant firm and plant characteristics that we include in our empirical model. However, we also explicitly correct for the possible endogeneity of the foreign acquisition dummy. To this end we firstly estimate a variant of the hazard model in equation (3) which instruments for the acquisition dummy using the probability of foreign acquisition (as in Table 5) as an instrument. As an alternative we use a propensity score matching approach in column (v).

The results based on the three alternative instrumental variables are reported in columns (ii) to (iv). Unfortunately there is, to the best of our knowledge, no formal method of choosing between the standard and the IV estimation in the context of a hazard model. Hence, preference of the IV model would be predicated on the assumption of endogenous acquisitions which is, strictly speaking, not reliably testable. However, we may use a 
standard Hausman test to get a rough indicator of whether or not the assumption of exogeneity holds. These tests, which are reported at the bottom of Table 6 provide evidence that in all cases we can reject the assumption of exogeneity of the acquisition dummy.

These results show that the point estimate of the effect of acquisition on exit is reduced (the coefficient is higher) and it is only statistically significant in one case in column (iv). The reliability of the IV approach hinges on the relevance and validity of the instruments used. While the relevance is to some extent shown in the IV generating probit in Table 5, there is, to the best of our knowledge, no test of instrument validity in the context of this non-linear hazard estimation. Hence, our results are reliable under the assumption of instrument validity, which cannot be tested.

We therefore use an approach which does not depend on such an assumption. We implement a propensity score matching procedure to generate a sample of acquired and non-acquired (matched) firms which can serve as a valid counterfactual. We then estimate equation (3) on this matched sample of firms, similar to Greenaway and Kneller (2007). The results are reported in column (v). Note that the acquisition effect is now statistically significant and positive. The point estimate suggests that the probability of surviving in plants within acquired firms is around 20 percent higher than in plants within non-acquired firms.

\section{Table 6 here}

We now consider various extensions to the baseline model. The first extension is concerned with the acquisition effect as such. The foreign acquisition effect we identify in the baseline estimation arguably includes two distinct components. First, acquisitions may affect plant survival independent of whether the acquirer is foreign or domestic. This may be termed a "pure acquisition effect”. Second, there may be a differential effect of foreign and domestic acquisitions, which may be considered as a "foreign effect". The analysis in the baseline model bundles these two effects together. This is a common problem in the literature (e.g., Arnold and Javorcik, 2005; Girma and Görg, 2007a, Petkova, 2007) and is usually difficult to address due to data limitations.

With our Swedish data we can make some progress on this issue. While, as in many other datasets, we do not observe domestic acquisitions directly we exploit the firm and plant 
dimension in our data. Specifically, plant and firm identifiers are linked together so we can follow the entity along both dimensions. If a plant remains within the same firm, both plant and firm identifier stay the same. If we observe a firm in t-1 but not in t, but observe its plants in both years, the plants will have a constant plant identifier but different "old" and "new" firm identifiers in t-1 and t respectively. We may then conclude from the data that the firm was acquired and that the new firm identifier relates to the acquiring firm. If this firm is not foreign, then we define this as a domestic takeover. In this way we identify 625 domestic acquisitions over the time period analysed in our data.

Another issue concerns the nature of the foreign acquisition. The literature broadly distinguishes foreign direct investments into horizontal and vertical (e.g, Alfaro and Charlton, 2009). There may arguably be different effects of foreign acquisitions on targets depending on these two motives. For example, horizontal acquisitions may involve substantial transfers of technology from the parent to the target, which may increase survival. However, it may also be about trying to eliminate rivals or consolidate the number of plants, leading to negative effects on survival probabilities. By contrast, acquisitions of vertically related suppliers may more likely lead to transfer of technology to improve or sustain quality, and hence may lead to strong positive effects on survival.

This is an issue that has not been investigated in the literature thus far, mainly due to data availability. We use our data and check the industry classification for the acquired firm before and after acquisition. If the two digit industry code remains constant, we define the acquisition as horizontal. If it is changed, it is instead regarded as vertical. Using this definition we classify about 11 percent of all foreign acquisitions in our sample as "vertical". This is not an ideal measure by any means. In particular, it is likely that our vertical group includes both "true" vertical acquisitions of, say, supplier firms, but also conglomerate mergers where the target and acquirer are in unrelated industries. Unfortunately, we do not have sufficient information to establish industry linkages. Still, the measure allows us to compare horizontal and other types of acquisitions. In order to do so we allow for separate acquisition effects for horizontal and vertical acquisitions. This is done interacting a dummy for horizontal acquisitions and the foreign acquisition dummy, and similarly for vertical acquisitions. 
The results of estimating equation (3) with these two modifications are reported in Table 7. Columns (i) to (iii) show the IV estimations. We use instruments for both foreign and domestic acquisition dummies. The instrument for the latter is constructed also using a probit equation of the probability of domestic acquisition, similar to equation (4). However, this probit model does not include the presence of foreign firms in the industry as regressor. From the IV estimations we find statistically significant positive effects from vertical acquisitions, while there is no evidence for an acquisition effect from horizontal takeovers. We also find that domestic acquisitions lead to improvements in the survival probabilities of the domestic plants, and these effects appear to be stronger than for foreign acquisitions. This conclusion also holds in the matching approach in column (iv), although the magnitude of the effects is reduced.

In column (iv) the matching is done using a probit modelling the determinants of the probability of acquisition, not distinguishing foreign and domestic. If the determinants are different for these two types of acquisitions, the matching procedure is not correct. We therefore provide two alternative estimations. In the first we only look at foreign acquisitions. We match using the probit model as described above and exclude from the sample all firms that are acquired by domestic firms. The results are reported in column (v). In the second approach we match only domestic acquisitions, excluding foreign acquisitions from the sample. The results are reported in column (vi). Both columns show results that are consistent with what we found in column (iv).

\section{Table 7 here}

In Table 2, we observed that, on average almost 90 percent of the plants that are within foreign acquired firms were plants of globally engaged firms, i.e. Swedish MNEs and exporting non-MNEs, before acquisition. We may expect that the survival prospect after foreign takeover differs depending on whether the plants were within targeted Swedish MNEs, exporting non-MNE or purely domestic firms. The recent literature on firm level heterogeneity makes the point that these firms have, a priori, differences in their characteristics (Helpman et al., 2004). This may not only affect their likelihood of being a takeover target but also the post acquisition effects on survival, as discussed above. 
To investigate whether there are indeed differences, we replace our foreign acquisition dummies in equation (3) with dummies showing the ownership status before foreign takeover; Acquired Swedish MNE, Acquired Swedish exporter and Acquired Swedish domestic. The first dummy equals one if the plants were within Swedish MNEs before foreign takeover and zero if the plants are within non-acquired firms. The second dummy takes the value of one if the plants were within exporters (non-MNEs) before foreign takeover and the last dummy shows whether the plants were within purely domestic firms before foreign takeover. We again allow the coefficients to be different for horizontal and vertical acquisitions.

Table 8 shows the results, which indicate that plants that are within targeted Swedish exporters have higher survival ratios after foreign takeover as compared to plants within nonacquired firms. These results are similar in direction for horizontal and vertical acquisitionis, but stronger in magnitude for the latter. These findings are also robust to the estimation strategy. The most conservative estimates in column (iv) and (v) suggest the survival ratio for acquired exporters improves by between 17 to 34 percent after foreign takeover for vertical, and 6 to 8 percent for horizontal acquisitions. There is, however, no robust evidence that acquisition impacts on the survival probabilities of either Swedish MNEs or purely domestic firms. This indicates that just looking at the acquisition effect without considering heterogeneity in the impact depending on firm characteristics may lead to biased conclusions. We show that only exporters experience increases in their survival prospects, and that it matters whether the acquisition is horizontal or non-horizontal. ${ }^{18}$

Why do we not find any effects for acquired MNEs or purely domestic firms? The former may be quite similar to their acquirer and, hence, have little to learn in terms of new technology coming in. This ties in with recent empirical work on productivity differences between firms, which shows that multinationals, regardless of whether they are domestic or foreign owned, have a productivity premium compared to purely domestic firms (Criscuolo and Martin, 2008). By contrast, purely domestic firms may be quite different from the acquirer in terms of their pre-acquisition characteristics. In fact, they may be too different to absorb the new knowledge and, hence, are not able to improve their survival chances significantly. Only exporters, which have a certain level of "absorptive capacity”, may be able to use the new knowledge that comes in with the foreign acquirer.

\footnotetext{
${ }^{18}$ Table A4 in the appendix presents the results estimating the specifications in columns (i) to (iv) using the random effects version of the cloglog model. These results are identical to those reported in Table 8.
} 
Table 8 here

\section{$5 \quad$ Employment effects}

Thus far we have considered the extensive margin of adjustment, namely the survival of the plants. Plant closure is, of course, not the only mechanism of adjustment after foreign acquisition. The acquisition may also lead to adjustment along the intensive margin for surviving plants, whereby the scale of the operations may be reduced or increased. Here we look at employment adjustment, as this is one of the most policy relevant plant performance measures, as it directly relates to concerns about job losses following foreign takeovers of previous national firms.

In order to estimate the impact of ownership change on employment growth in acquired plants we adopt a differences-in-differences methodology. The first step proceeds by comparing the average employment growth $\dot{E}$ before acquisition with its post-acquisition counterpart. However, the resulting quantity, say, $\Delta^{a} \dot{E}$, is a biased estimator of the impact of the ownership change on employment growth since it is likely to be affected by other factors which are contemporaneous with the acquisition. Now consider the changes in employment growth of the control plants corresponding to the pre and post acquisitions periods, say, $\Delta^{c} \dot{E}$. If exogenous shocks which are contemporaneous with the acquisitions affect the acquired and control firms in more or less similar fashions, the differences-in-differences estimator which is defined as $\delta=\Delta^{a} \dot{E}-\Delta^{c} \dot{E}$ would purge the effects of common shocks and provide an unbiased estimator of the impact of ownership change.

To implement the above methodology within a regression framework, one can estimate the following equation, using the sample of acquired plants plus the control group:

$$
\dot{E}_{i t}=\alpha+\delta \text { Acquisition }_{i}+\varepsilon_{i t}
$$

Here $i$ and $t$ index plants and time periods respectively and Acquisition is as before a dummy equal to one if the plant is acquired by a foreign owner. In equation (5) the estimator for $\delta$ 
yields the average percentage point change in the growth rate of employment that can be attributed to foreign acquisitions.

In our empirical implementation, we extend the basic regression framework in several directions. Firstly, we allow for different effects of foreign acquisitions of Swedish MNEs, exporters, and purely domestic firms, as in the hazard model in Table 8. We also include interaction terms for vertical acquisitions, and include a dummy for domestic acquisitions in the control group in order to identify a "foreign acquisition” effect. Furthermore, year dummies and industry-specific effects are included to capture aggregate shocks and permanent differences in the trend of employment growth across sectors respectively. A vector of plant and firm characteristics is also included to control for observable changes that are potentially correlated with employment changes. This vector consists of the growth of labor productivity, capital intensity and R\&D intensity, plant age, employment level in t-1, plants skill intensity relative to the industry mean skill intensity, a dummy capturing whether the plant belongs to a multi-plant firm and a dummy variable that is equal to one if another plant in the same firm exited.

The above methodology assumes that foreign acquisitions are exogenous to the process underlying the process of employment dynamics of the acquired plants. However, if employment growth plays some role in driving acquisitions, then it is possible that the acquisition indicators may be endogenous to equation (5). As above, possible endogeneity may be allowed for by using the estimate of the probability of foreign acquisition as an instrument, or selecting a control group based on propensity score matching. ${ }^{19}$

The results of the estimation of equation (5) using IV estimation as well as estimation of the model using a matched sample are reported in Table 9. What is notable is that adjustment along the intensive margin of employment is somewhat different than adjustment along the extensive margin of plant survival. While we found that both vertical and horizontal foreign acquisitions raise the survival probabilities of domestic exporters (not MNEs) only, employment growth is higher after vertical acquisitions in Swedish exporters. Based on the matched sample in column (iv), a foreign acquisition leads to an increase in employment growth by roughly 4 to 5 percent for Swedish exporters. Furthermore, we find that the effect

\footnotetext{
${ }^{19}$ Vella and Verbeek (1999) have shown that this type of instrumental variables (IV) approach generates estimates comparable to Heckman's (1978) well-known endogeneity bias corrected OLS estimator.
} 
of domestic acquisitions is also positive, but only statistically significant in two out of four cases. As before, we still find, however, that there are no foreign acquisition effects if the target is a purely domestic firm. The post acquisitions effects for Swedish MNE are positive, but not robust across different estimation techniques.

\section{Table 9 here}

\section{Conclusions}

This paper has investigated the effect of foreign acquisition on plant survival and employment growth in the Swedish manufacturing during the 1990s. To this end we have used a unique dataset where firm and plant level information is linked together. This means that we are able to use firm information, as well as characteristics at the plant level.

Controlling for possible endogeneity of the acquisition dummy by using an instrumental variable approach and a matched sample, and also controlling for other plant and firm specific characteristics, the result reveals that survival ratio for acquired exporters, but not other types of firms, improves post acquisition. Depending on whether the acquisition is in the same industry (horizontal) or not (vertical) the point estimates suggest that survival increases by between 17 to 34 percent after foreign takeover for vertical, and 6 to 8 percent for horizontal acquisitions. We also find that employment growth is higher in takeover targets that were exporters prior to acquisition.

There are important implications of this finding for researchers and policy makers. Firstly, foreign acquisition appears to have overall positive or neutral effects on survival and employment growth of targets. There is no evidence of negative effects. Hence, strong fears as to the sustainability of domestic industry in the light of increasing foreign acquisitions appear unfounded. Secondly, when judging the magnitude of these effects it is important to take into account aspects of firm level heterogeneity, as not all types of firms benefit equally in terms of higher survival prospects or employment growth from foreign acquisition. 


\section{References}

[1] Alfaro, L. and A. Charlton (2009), Intra-industry foreign direct investment, American Economic Review, forthcoming

[1] Almeida, R.K. (2007), The Effects of Foreign Owned Firms on the Labor Market, Journal of International Economics, 71, 75-96

[2] Arnold, J. and B.S. Javorcik. (2005) “Gifted Kids or Pushy Parents? Foreign Acquisitions and Plant Performance in Indonesia.“ CEPR Discussion Paper 5065.

[3] Audretsch, D.B. and Mahmood, T. (1995), New-Firm Survival: New Results using a Hazard Function, Review of Economics and Statistics 77, 97-103

[4] Bernard, A. and Jensen, B. (2007), 'Firm structure, multinationals and manufacturing plant deaths', Review of Economics and Statistics, 89, 193-204.

[5] Bernard, A. and Sjöholm, F. (2003), 'Foreign owners and plant survival', NBER working paper 10039.

[6] Coles, J., M. Lemon, F. Meschke (2007), Structural Models and Endogeneity in Corporate Finance: the Link Between Managerial Ownership and Corporate Performance, mimeo

[7] Conyon, M.J., Girma, S., Thompson, S. and Wright, P.W. (2002): "The Impact of Foreign Acquisition on Wages and Productivity in the United Kingdom”, Journal of Industrial Economics, Vol. 50, pp. 85-102.

[8] Criscuolo, C. and R. Martin (2008), Multinationals and the US productivity leadership: Evidence from Britain, Review of Economics and Statistics, forthcoming.

[9] Disney, R., J. Haskel and Y. Heden (2003): “Entry, exit and establishment survival in UK manufacturing”, Journal of Industrial Economics, Vol. 51, pp. 91-112

[10] Fukao, K., K. Ito, H. Kwon, M. Takizawa (2006), Cross border acquisitions and target firm performance: Evidence from Japanese firm level data, NBER Working Paper No. 12422

[11] Girma, S. and Görg, H. (2004), Blessing or Curse? Domestic plants survival and employment prospects after foreign acquisition, Applied Economics Quarterly, 50, 89110.

[12] Girma, S. and Görg, H. (2007a), "Evaluating the foreign ownership wage premium using a difference-in-differences matching approach", Journal of International Economics, 72(1), 97-112

[13] Girma, S. and Görg, H. (2007b), "Multinationals' productivity advantage: Scale or technology?”, Economic Inquiry, Vol. 45, No. 2, pp. 350-362 
[14] Greenaway, D. and R. Kneller (2007), Firm heterogeneity, exporting and foreign direct investment', The Economic Journal . Vol. 117, Issue 517, pp. F134-161.

[15] Greenaway, D. and R. Kneller (2008), Exporting, productivity and agglomeration, European Economic Review, 52(5), 919-939

[16] Hansson; P, Karpaty, P, Lindvert, M, Lundberg, L, Poldahl, A. and Yun, L. (2007), Svenskt näringsliv i en globaliserad värld. ITPS A2007:4.

[17] Harris, R. and Robinson, C. (2002). 'The effect of foreign acquisitions on total factor productivity: Plant-level evidence from U.K manufacturing, 1987-1992', Review of Economics and Statistics, Vol. 84, pp. 562-568

[18] Harris, R., D. Siegel and M. Wright (2005), Assessing the Impact of Management Buyouts on Economic Efficiency: Plant-Level Evidence from the United Kingdom, Review of Economics and Statistics, 87(1), 148-153

[19] Head, K. and J. Ries (2008), FDI as an outcome of the market for corporate control: Theory and evidence, Journal of International Economics,

[20] Heckman, J.J. (1978): "Dummy endogenous variables in a simultaneous equation system”, Econometrica, Vol. 46, pp. 931-959.

[21] Helpman, E., M. Melitz and S. Yeaple (2004), Export versus FDI with heterogeneous firms, American Economic Review, 94, 300-316

[22] Hijzen, A., H. Görg and M. Manchin (2008), Cross-border mergers \& acquisitions and the role of trade costs, European Economic Review, 52(5), 849-866

[23] Hujer, R., K. Maurer and M. Wellner (1999), Estimating the effect of vocational training on unemployment duration in West Germany - A discrete hazard-rate model with instrumental variables, Jahrbücher für Nationalökonomie und Statistik, 218, 619-646

[24] Huttunen, K. (2007), The effect of foreign acquisition on employment and wages: Evidence from Finnish establishments, Review of Economics and Statistics, 89(3), 497509

[25] Leuven, E. and Sianesi, B. (2003), PSMATCH2: Stata module to perform full Mahalanobis and propensity score matching, common support graphing, and covariate imbalance testing. Available at http://ideas.repec.org/c/boc/bocode/s432001.html.

[26] Mata, J. and Portugal, P. (2002), 'The survival of new domestic and foreign-owned firms’, Strategic Management Journal, 23, 323-343.

[27] McGuckin, R.H. and S.V. Nguyen (2001), The impact of ownership changes: A view from labor markets, International Journal of Industrial Organization, 19, 739-762.

[28] Neary, J.P. (2007), Cross-border mergers as instruments of comparative advantage, Review of Economic Studies, 74(4), 1229-1257 
[29] Petkova, N. (2007), Does foreign ownership lead to higher productivity?, mimeo, University of Michigan

[30] Prentice, R.L. and Gloeckler, L.A. (1978), "Regression analysis of grouped survival data with application to breast cancer data”, Biometrics, Vol 34 pp. 57-67.

[31] Thompson, S. (1999): “Takeovers, joint ventures and the acquisition of resources for diversification”, Scottish Journal of Political Economy, Vol. 46, pp. 303-318

[32] UNCTAD (2007), World Investment Report 2007, New York: United Nations

[33] Van Beveren, I. (2007), 'Footloose multinationals in Belgium?' Review of World Economics, 143(3)

[34] Vella, F and Verbeek, M. (1999): "Estimating and interpreting models with endogenous treatment effects”, Journal of Business and Economic Statistics, Vol. 17, pp. 473-478.

[35] Wagner, Joachim. 2007. "Exports and Productivity: A Survey of the Evidence from Firm-level Data.” The World Economy 30, 1, 60-82. 
Table 1 Foreign MNEs, Swedish MNEs and exporting non-MNEs: Number of plants and employment shares 1993-2002

\begin{tabular}{|c|c|c|c|c|c|c|}
\hline \multirow{2}{*}{ Year } & \multicolumn{2}{|c|}{ Foreign MNEs } & \multicolumn{2}{c|}{ Swedish MNEs } & \multicolumn{2}{c|}{ Exporting non-MNEs } \\
\cline { 2 - 7 } & $\begin{array}{c}\text { Plants } \\
\text { (Percent) }\end{array}$ & $\begin{array}{c}\text { Employment } \\
\text { Percent }\end{array}$ & $\begin{array}{c}\text { Plants } \\
\text { (Percent) }\end{array}$ & $\begin{array}{c}\text { Employment } \\
\text { Percent }\end{array}$ & $\begin{array}{c}\text { Plants } \\
\text { (Percent) }\end{array}$ & $\begin{array}{c}\text { Employment } \\
\text { Percent }\end{array}$ \\
\hline 1993 & $1,402(25.8)$ & 21.5 & $1,722(31.6)$ & 53.3 & $1,141(21.0)$ & 16.1 \\
1994 & $1,476(27.4)$ & 21.1 & $1,911(35.5)$ & 57.3 & $1,141(21.2)$ & 14.8 \\
1995 & $1,534(29.1)$ & 22.0 & $1,618(30.6)$ & 55.1 & $1,156(21.9)$ & 15.3 \\
1996 & $1,624(31.5)$ & 27.4 & $1,495(29.0)$ & 50.4 & $1,238(24.0)$ & 14.9 \\
1997 & $1,490(28.9)$ & 27.8 & $1,761(34.2)$ & 51.8 & $1,044(20.3)$ & 14.7 \\
1998 & $1,686(31.8)$ & 30.8 & $1,536(29.0)$ & 48.4 & $1,077(20.3)$ & 15.3 \\
1999 & $1,774(37.7)$ & 34.9 & $1,180(25.1)$ & 43.6 & $943(20.1)$ & 16.1 \\
2000 & $1,837(37.3)$ & 41.1 & $1,385(28.1)$ & 38.8 & $958(19.4)$ & 14.7 \\
2001 & $2,051(41.6)$ & 46.8 & $1,216(24.6)$ & 32.2 & $954(19.3)$ & 16.0 \\
2002 & $1,815(40.5)$ & 48.3 & $1,123(25.1)$ & 32.3 & $850(19.0)$ & 13.1 \\
\hline $1993-2002$ & $16,689(32.9)$ & 32.2 & $14,947(29.5)$ & 46.3 & $10,502(20.7)$ & 15.1 \\
\hline \multicolumn{7}{|c|}{ Number of unique plants } \\
\hline $1993-2002$ & $4,305(29.5)$ & $4,684(32.1)$ & & $3,047(20.9)$ & \\
\hline
\end{tabular}

Table 2 Frequency of foreign acquisitions: Number of plants and employment shares

\begin{tabular}{|c|c|c|c|c|c|c|c|c|c|}
\hline \multirow[b]{2}{*}{ Year } & \multicolumn{3}{|c|}{$\begin{array}{l}\text { Swedish MNEs to } \\
\text { foreign MNEs }\end{array}$} & \multicolumn{3}{|c|}{$\begin{array}{l}\text { Exporting non-MNEs to } \\
\text { foreign MNEs }\end{array}$} & \multicolumn{3}{|c|}{$\begin{array}{l}\text { Non-exporting non-MNEs to } \\
\text { foreign MNEs }\end{array}$} \\
\hline & $\begin{aligned} & \mathrm{Pl}_{\mathrm{c}} \\
&(\mathrm{Pel}\end{aligned}$ & & $\begin{array}{l}\text { Employment } \\
\text { share* }\end{array}$ & $\begin{aligned} \mathrm{Pl} \\
(\mathrm{Pel}\end{aligned}$ & & $\begin{array}{l}\text { Employment } \\
\text { share* }\end{array}$ & $\begin{aligned} \text { Pla } \\
\text { Perc }\end{aligned}$ & & $\begin{array}{l}\text { Employment } \\
\text { share* }\end{array}$ \\
\hline 1994 & 7 & $(9.2)$ & 19.4 & 51 & $(67.1)$ & 66.7 & 18 & (23.7) & 13.9 \\
\hline 1995 & 19 & $(20.0)$ & 30.0 & 74 & (77.9) & 68.8 & 2 & $(2.1)$ & 1.2 \\
\hline 1996 & 161 & (55.5) & 72.1 & 123 & (42.4) & 26.1 & 6 & $(2.1)$ & 1.8 \\
\hline 1997 & 8 & (18.2) & 26.0 & 23 & (52.3) & 57.8 & 13 & (29.5) & 16.2 \\
\hline 1998 & 25 & (41.7) & 74.8 & 34 & (56.7) & 19.4 & 1 & $(1.7)$ & 5.9 \\
\hline 1999 & 78 & (72.2) & 77.3 & 23 & (21.3) & 15.3 & 7 & $(6.5)$ & 7.4 \\
\hline 2000 & 20 & (41.7) & 88.0 & 14 & $(29.2)$ & 10.6 & 14 & (29.2) & 1.4 \\
\hline 2001 & 5 & (1.9) & 4.0 & 217 & (82.8) & 85.0 & 40 & (15.3) & 11.0 \\
\hline 2002 & 13 & (26.0) & 26.9 & 34 & $(68.0)$ & 65.8 & 3 & $(6.0)$ & 7.3 \\
\hline 1993-2002 & 336 & (32.5) & 46.5 & 593 & (57.4) & 46.2 & 104 & (10.1) & 7.3 \\
\hline
\end{tabular}

Notes: * Share of total employment in plants within acquired firms 
Table 3 Mean variable differences between acquired and non-acquired firms in the preacquisition period, whole sample.

\begin{tabular}{|c|c|c|c|}
\hline Plant variables & $\mathrm{T}=0$ & $\mathrm{~T}=-1$ & $\mathrm{~T}=-2$ \\
\hline Employment & 22 & 35 & 52 \\
& $(2.48)^{* * *}$ & $(3.71)^{* * *}$ & $(4.69)^{* * *}$ \\
Age & -1.82 & -1.11 & -1.01 \\
& $(9.27)^{* * *}$ & $(5.47)^{* * *}$ & $(4.26)^{* * *}$ \\
Skill intensity & -0.07 & -0.01 & -0.13 \\
& $(1.09)$ & $(0.16)$ & $(1.57)$ \\
Obs. Target/Non-target & $907 / 28,490$ & $808 / 27,411$ & $572 / 26,784$ \\
\hline \multicolumn{3}{|c|}{} \\
\hline Firm variables & $\mathrm{T}=0$ & $\mathrm{~T}=-1$ & $\mathrm{~T}=-2$ \\
\hline Employment & 170 & 175 & 156 \\
Skill intensity & $(2.54)^{* *}$ & $(2.52)^{* *}$ & $(2.05)^{* *}$ \\
R\&D intensity & 3.1 & 2.5 & 2.7 \\
& $(3.66)^{* * *}$ & $(2.93)^{* * *}$ & $(2.97)^{* * *}$ \\
Capital-labor & 0.7 & 0.8 & 0.7 \\
Ratio & $(2.52)^{* *}$ & $(2.98)^{* * *}$ & $(2.61)^{* * *}$ \\
Shipment & 39.6 & 75.5 & 39.0 \\
& $(0.64)$ & $(2.22)^{* *}$ & $(1.06)$ \\
Export intensity & 451 & 444 & 389 \\
Productivity & $(1.76)^{*}$ & $(1.90)^{* *}$ & $(1.68)^{*}$ \\
& 8.2 & 8.1 & 6.0 \\
Obs. Target/Non-target & $207 / 7,456$ & $198 / 6,932$ & $168 / 6,425$ \\
\hline
\end{tabular}


Table 4 Kaplan-Meier survival function, indigenous plants by firm type

\begin{tabular}{|c|c|c|c|}
\hline Time & \multicolumn{3}{|c|}{ Whole sample } \\
\hline & Non-Exporter & Exporter & Swedish MNE \\
\hline 1 & 93.1 & 89.2 & 86.5 \\
& $(0.005)$ & $(0.006)$ & $(0.005)$ \\
\hline 2 & 80.3 & 78.8 & 78.8 \\
& $(0.008)$ & $(0.008)$ & $(0.006)$ \\
\hline 3 & 71.2 & 73.0 & 70.1 \\
& $(0.010)$ & $(0.008)$ & $(0.007)$ \\
\hline 4 & 64.1 & 68.6 & 60.0 \\
& $(0.010)$ & $(0.009)$ & $(0.007)$ \\
\hline 5 & 53.0 & 58.1 & 47.8 \\
& $(0.026)$ & $(0.010)$ & $(0.008)$ \\
\hline 6 & 48.2 & 50.4 & 42.2 \\
& $(0.011)$ & $(0.010)$ & $(0.008)$ \\
\hline 7 & 39.6 & 46.0 & 34.6 \\
& $(0.011)$ & $(0.010)$ & $(0.007)$ \\
\hline 8 & 30.4 & 35.6 & 28.3 \\
& $(0.010)$ & $(0.010)$ & $(0.007)$ \\
\hline 9 & 30.4 & 35.6 & 28.2 \\
& $(0.010)$ & $(0.009)$ & $(0.007)$ \\
\hline
\end{tabular}

Notes: Standard error is within parentheses 
Table 5 Probability of foreign acquisition - The Probit model

\begin{tabular}{|c|c|c|c|}
\hline Variables & (i) & (ii) & (iii) \\
\hline Export intensity & $\begin{array}{c}0.296 \\
(3.42)^{* * *}\end{array}$ & $\begin{array}{c}0.276 \\
(3.17)^{* * *}\end{array}$ & $\begin{array}{c}0.419 \\
(8.25)^{* * *}\end{array}$ \\
\hline $\mathrm{R} \& \mathrm{D}$ intensity & $\begin{array}{l}0.524 \\
(0.94)\end{array}$ & $\begin{array}{l}0.524 \\
(0.94)\end{array}$ & $\begin{array}{l}0.524 \\
(0.94)\end{array}$ \\
\hline Relative employment & $\begin{array}{l}0.003 \\
(1.01)\end{array}$ & $\begin{array}{l}0.004 \\
(0.12)\end{array}$ & $\begin{array}{l}0.003 \\
(1.48)\end{array}$ \\
\hline Labor productivity & $\begin{array}{c}0.127 \\
(2.11)^{* *}\end{array}$ & $\begin{array}{l}0.065 \\
(0.98)\end{array}$ & $\begin{array}{c}0.207 \\
(5.22)^{* * *}\end{array}$ \\
\hline Skill intensity & $\begin{array}{c}0.077 \\
(1.88)^{*}\end{array}$ & $\begin{array}{c}0.087 \\
(2.17)^{* *}\end{array}$ & $\begin{array}{c}0.160 \\
(7.56)^{* * *}\end{array}$ \\
\hline Age & $\begin{array}{c}-0.077 \\
(5.42)^{* * *}\end{array}$ & $\begin{array}{c}-0.076 \\
(5.35)^{* * *}\end{array}$ & $\begin{array}{c}-0.048 \\
(5.75)^{* * *}\end{array}$ \\
\hline$(\text { Age })^{2}$ & $\begin{array}{c}0.002 \\
(4.35)^{* * * *}\end{array}$ & $\begin{array}{c}0.002 \\
(4.21)^{* * *}\end{array}$ & $\begin{array}{c}0.001 \\
(5.52)^{* * *}\end{array}$ \\
\hline Foreign presence & $\begin{array}{c}0.064 \\
(2.14)^{* *}\end{array}$ & $\begin{array}{c}0.059 \\
(1.95)^{*}\end{array}$ & $\begin{array}{c}0.127 \\
(7.33)^{* * *}\end{array}$ \\
\hline Capital intensity & & $\begin{array}{c}0.042 \\
(2.11)^{* *}\end{array}$ & \\
\hline Sales & & & $\begin{array}{c}0.016 \\
(2.98)^{* * *}\end{array}$ \\
\hline Year dummies & Yes & Yes & Yes \\
\hline $\begin{array}{c}\text { Pseudo } \mathrm{R}^{2} \\
\text { LR chi2(16) } \\
\text { Observations }\end{array}$ & $\begin{array}{c}0.050 \\
112.24 \\
9.716\end{array}$ & $\begin{array}{c}0.052 \\
114.89 \\
9.716 \\
\end{array}$ & $\begin{array}{c}0.054 \\
118.53 \\
9.716\end{array}$ \\
\hline
\end{tabular}

Notes: Z-statistics is within parenthesis. Relative employment is firm's employment relative to the industry mean employment. Apart from age and age $^{2}$, all the other variables are lagged one period. The share of foreign employment at industry level (SNI92 2-digit level) is used as proxy for foreign presence. ***, **, * indicate significance at 1, 5 and 10 percent levels, respectively. 
Table 6

Result of Cox Hazard model. Foreign and domestic acquisition of plants of all Swedish manufacturing firms.

\begin{tabular}{|c|c|c|c|c|c|}
\hline & $\begin{array}{l}\text { Exogenous } \\
\text { acquisition }\end{array}$ & IV 1 & IV 2 & IV 3 & $\begin{array}{c}\text { Matched } \\
\text { sample } \\
\end{array}$ \\
\hline & (i) & (ii) & (iii) & (iv) & $(\mathrm{v})$ \\
\hline \multirow[t]{2}{*}{ Foreign acquisition } & 0.689 & 0.914 & 0.904 & 0.888 & 0.786 \\
\hline & $(8.91)^{* * *}$ & $(0.94)$ & (1.13) & $(1.78)^{*}$ & $(5.38)^{* * *}$ \\
\hline \multicolumn{6}{|l|}{ Plant level controls } \\
\hline \multirow[t]{2}{*}{ Age } & 0.249 & 0.251 & 0.251 & 0.251 & 0.267 \\
\hline & $(77.90)^{* * *}$ & $(79.65)^{* * *}$ & $(69.19)^{* * *}$ & $(74.63)^{* * *}$ & $(58.30)^{* * *}$ \\
\hline \multirow[t]{2}{*}{ Size } & 0.817 & 0.818 & 0.818 & 0.818 & 0.825 \\
\hline & $(15.64)^{* * * *}$ & $(15.47)^{* * *}$ & $(15.00)^{* * *}$ & $(13.92)^{* * *}$ & $(12.51)^{* * *}$ \\
\hline \multirow[t]{2}{*}{ Skill intensity } & 0.986 & 0.986 & 0.986 & 0.986 & 0.997 \\
\hline & $(2.57)^{* * *}$ & $(2.50)^{* *}$ & $(2.76)^{* * *}$ & $(2.43)^{* *}$ & $(0.38)$ \\
\hline \multicolumn{6}{|l|}{ Firm level controls } \\
\hline \multirow[t]{2}{*}{ Multiplant } & 0.905 & 0.921 & 0.921 & 0.921 & 1.711 \\
\hline & $(1.22)$ & $(0.94)$ & $(1.02)$ & $(0.94)$ & $(4.83)^{* * *}$ \\
\hline \multirow[t]{2}{*}{ Failed other plant } & 0.537 & 0.533 & 0.533 & 0.533 & 0.826 \\
\hline & $(16.32)^{* * *}$ & $(16.03)^{* * *}$ & $(16.55)^{* * *}$ & $(16.15)^{* * *}$ & $(4.34)^{* * *}$ \\
\hline \multirow{2}{*}{ Capital intensity } & 1.100 & 1.086 & 1.087 & 1.087 & 1.082 \\
\hline & $(9.61)^{* * *}$ & $(7.87)^{* * *}$ & $(8.63)^{* * *}$ & $(8.38)^{* * *}$ & $(6.52)^{* * *}$ \\
\hline \multirow[t]{2}{*}{ R\&D intensity } & 0.728 & 0.761 & 0.764 & 0.771 & 0.437 \\
\hline & $(0.86)$ & $(0.70)$ & $(0.84)$ & $(0.70)$ & $(2.01)^{* *}$ \\
\hline \multirow[t]{2}{*}{ Labor productivity } & 0.658 & 0.657 & 0.657 & 0.657 & 0.722 \\
\hline & $(11.81)^{* * *}$ & $(11.11)^{* * *}$ & $(11.68)^{* * *}$ & $(13.48)^{* * *}$ & $(7.45)^{* * * 4}$ \\
\hline Observation & 31,047 & 31,047 & 31,047 & 31,047 & 19,784 \\
\hline Wald Chi Square & 10,627 & 14,535 & 9,343 & 15,121 & 6,910 \\
\hline Hausman test (p-value) & & 0.002 & 0.002 & 0.002 & \\
\hline \multirow[t]{2}{*}{ Linktest (hatsq) } & 0.009 & 0.006 & 0.010 & 0.005 & -0.004 \\
\hline & $(1.25)$ & $(1.07)$ & (1.38) & $(0.97)$ & $(0.40)$ \\
\hline
\end{tabular}

Notes: Estimations are stratified by industry and year. Industries are defined at the SNI92 2-digit level (22 industries). Standard errors in parentheses. ${ }^{* * *}, * * *$ indicate significance at 1,5 and 10 percent levels, respectively. Only plants in firms with 50 employees or more are included. 
Table 7

Result of Cox Hazard model. Foreign and domestic acquisition of plants of all Swedish manufacturing firms.

\begin{tabular}{|c|c|c|c|c|c|c|}
\hline & IV & IV 2 & IV 3 & $\begin{array}{l}\text { Matched } \\
\text { sample }\end{array}$ & $\begin{array}{l}\text { Matched } \\
\text { sample }\end{array}$ & $\begin{array}{c}\text { Matched } \\
\text { sample }\end{array}$ \\
\hline & (i) & (ii) & (iii) & (iv) & $(\mathrm{v})$ & (vi) \\
\hline \multirow[t]{2}{*}{ Vertical acquisition } & 0.362 & 0.347 & 0.403 & 0.736 & 0.786 & \\
\hline & $(2.88)^{* * *}$ & $(3.02)^{* * *}$ & $(2.92)^{* * *}$ & $(6.81)^{* * *}$ & $(4.67)^{* * *}$ & \\
\hline \multirow[t]{2}{*}{ Horizontal acquisition } & 0.815 & 0.862 & 0.704 & 0.852 & 0.889 & \\
\hline & $(0.09)$ & $(0.15)$ & $(1.07)$ & $(0.99)$ & $(0.81)$ & \\
\hline \multirow[t]{2}{*}{ Domestic acquisition } & 0.176 & 0.188 & 0.166 & 0.466 & & 0.424 \\
\hline & $(8.51)^{* . * 4}$ & $(8.76)^{* * \pi}$ & $(9.33)^{* * *}$ & $(7.79)^{* * * *}$ & & $(7.09)^{* *+8}$ \\
\hline \multicolumn{7}{|l|}{ Plant level controls } \\
\hline \multirow[t]{2}{*}{ Age } & 0.264 & 0.247 & 0.246 & 0.278 & 0.261 & 0.267 \\
\hline & $(75.22)^{* * * *}$ & $(75.22)^{* * *}$ & $(74.84)^{* * *}$ & $(56.01)^{* * *}$ & $(46.71)^{* * * *}$ & $(36.63)^{* * *}$ \\
\hline \multirow[t]{2}{*}{ Size } & 0.822 & 0.825 & 0.823 & 0.836 & 0.822 & 0.845 \\
\hline & $(15.29)^{* * *}$ & $(15.32)^{* * *}$ & $(15.21)^{* * *}$ & $(11.54)^{* * *}$ & $(10.17)^{* * * *}$ & $(7.54)^{* * * *}$ \\
\hline \multirow{2}{*}{ Skill intensity } & 0.982 & 0.982 & 0.982 & 0.996 & 1.005 & 0.997 \\
\hline & $(3.22)^{* * *}$ & $(3.21)^{* * *}$ & $(3.22)^{* * *}$ & $(0.64)$ & $(0.57)$ & $(0.31)$ \\
\hline \multicolumn{7}{|l|}{ Firm level controls } \\
\hline \multirow[t]{2}{*}{ Multiplant } & 0.878 & 0.875 & 0.886 & 1.812 & 1.900 & 1.547 \\
\hline & $(1.79)^{*}$ & $(1.85)^{*}$ & $(1.67)^{*}$ & $(5.28)^{* * *}$ & $(4.72)^{* * *}$ & $(2.18)^{* *}$ \\
\hline \multirow[t]{2}{*}{ Failed other plant } & 0.545 & 0.543 & 0.543 & 0.831 & 0.663 & 1.349 \\
\hline & $(14.95)^{* * *}$ & $(14.99)^{* * *}$ & $(14.98)^{* * *}$ & $(4.17)^{* * *}$ & $(7.35)^{* * *}$ & $(4.23)^{* * *}$ \\
\hline \multirow[t]{2}{*}{ Capital intensity } & 1.081 & 1.089 & 1.087 & 1.078 & 1.062 & 1.158 \\
\hline & $(7.63)^{* * *}$ & $(8.47)^{* * * *}$ & $(8.18)^{* * *}$ & $(6.18)^{* * *}$ & $(3.79)^{* * *}$ & $(8.50)^{* * * *}$ \\
\hline \multirow[t]{2}{*}{ R\&D intensity } & 0.901 & 0.875 & 0.875 & 0.439 & 0.302 & 0.212 \\
\hline & $(0.28)$ & $(0.36)$ & $(0.36)$ & $(1.99)^{* *}$ & $(2.83)^{* * *}$ & $(2.01)^{* *}$ \\
\hline \multirow[t]{2}{*}{ Labor productivity } & 0.621 & 0.619 & 0.615 & 0.701 & 0.743 & 0.539 \\
\hline & $(13.43)^{* * * *}$ & $(13.56)^{\text {**** }}$ & $(13.60)^{* * *}$ & $(8.24)^{* * * *}$ & $(5.26)^{* * *}$ & $(11.39)^{* * * *}$ \\
\hline Observation & 31,047 & 31,047 & 31,047 & 19,784 & 13,395 & 9,394 \\
\hline Wald Chi Square & 13,549 & 13,664 & 13,467 & 6,731 & 4,734 & 2,902 \\
\hline Hausman test (p-value) & 0.001 & 0.001 & 0.002 & & & \\
\hline \multirow[t]{2}{*}{ Linktest (hatsq) } & 0.006 & 0.008 & 0.004 & 0.001 & 0.021 & -0.014 \\
\hline & $(1.06)$ & (1.13) & $(1.06)$ & $(0.05)$ & $(2.15)^{* *}$ & (1.19) \\
\hline
\end{tabular}

Notes: Estimations are stratified by industry and year. Industries are defined at the SNI92 2-digit level (22 industries). Standard errors in parentheses. ${ }^{* * *},{ }^{* *}, *$ indicate significance at 1,5 and 10 percent levels, respectively. Only plants in firms with 50 employees or more are included. In column (v) plants within firms taken over by other domestic firms are excluded and in column (vi) plants within firms taken over by foreign MNEs are excluded. 
Table 8 Result of Cox Hazard model. Foreign acquisition of Swedish MNE plants and plants of exporting and non-exporting firms.

\begin{tabular}{|c|c|c|c|c|c|}
\hline & (i) & (ii) & (iii) & (iv) & (v) \\
\hline & IV 1 & IV 2 & IV 3 & $\begin{array}{l}\text { Matched } \\
\text { sample }\end{array}$ & $\begin{array}{c}\text { Matched } \\
\text { sample }\end{array}$ \\
\hline $\begin{array}{l}\text { Vertical acquired } \\
\text { Swedish MNE }\end{array}$ & $\begin{array}{c}0.643 \\
(1.94)^{* *}\end{array}$ & $\begin{array}{l}0.775 \\
(1.78)^{*}\end{array}$ & $\begin{array}{l}1.387 \\
(0.63)\end{array}$ & $\begin{array}{c}0.866 \\
(1.69)^{*}\end{array}$ & $\begin{array}{l}1.014 \\
(0.11)\end{array}$ \\
\hline $\begin{array}{l}\text { Vertical acquired } \\
\text { Swedish exporter }\end{array}$ & $\begin{array}{c}0.221 \\
(4.53)^{* * *}\end{array}$ & $\begin{array}{c}0.235 \\
(4.70)^{* * *}\end{array}$ & $\begin{array}{c}0.309 \\
(3.80)^{* * *}\end{array}$ & $\begin{array}{c}0.658 \\
(3.67)^{* * *}\end{array}$ & $\begin{array}{l}0.824 \\
(1.98)^{* *}\end{array}$ \\
\hline $\begin{array}{l}\text { Vertical acquired } \\
\text { Swedish domestic }\end{array}$ & $\begin{array}{l}1.187 \\
(0.33)\end{array}$ & $\begin{array}{l}1.578 \\
(1.01)\end{array}$ & $\begin{array}{l}0.808 \\
(0.27)\end{array}$ & $\begin{array}{l}1.594 \\
(1.54)\end{array}$ & $\begin{array}{l}1.620 \\
(1.53)\end{array}$ \\
\hline $\begin{array}{l}\text { Horizontal acquired } \\
\text { Swedish MNE }\end{array}$ & $\begin{array}{l}0.985 \\
(0.21)\end{array}$ & $\begin{array}{l}1.057 \\
(0.46)\end{array}$ & $\begin{array}{l}1.301 \\
(0.74)\end{array}$ & $\begin{array}{l}1.220 \\
(0.32)\end{array}$ & $\begin{array}{l}1.471 \\
(0.98)\end{array}$ \\
\hline $\begin{array}{l}\text { Horizontal acquired } \\
\text { Swedish exporter }\end{array}$ & $\begin{array}{c}0.700 \\
(2.35)^{* *}\end{array}$ & $\begin{array}{c}0.750 \\
(2.29)^{* * *}\end{array}$ & $\begin{array}{c}0.701 \\
(2.75)^{* * *}\end{array}$ & $\begin{array}{c}0.920 \\
(2.08)^{* * * *}\end{array}$ & $\begin{array}{c}0.934 \\
(2.12)^{* * * *}\end{array}$ \\
\hline $\begin{array}{l}\text { Horizontal acquired } \\
\text { Swedish domestic }\end{array}$ & $\begin{array}{l}1.352 \\
(0.55)\end{array}$ & $\begin{array}{l}2.162 \\
(0.96)\end{array}$ & $\begin{array}{l}1.750 \\
(0.96)\end{array}$ & $\begin{array}{l}2.645 \\
(1.22)\end{array}$ & $\begin{array}{l}1.061 \\
(0.88)\end{array}$ \\
\hline Domestic acquisition & 0.186 & 0.191 & 0.157 & 0.467 & \\
\hline & $(7.77)^{* * *}$ & $(8.58)^{* * *}$ & $(9.09)^{* * *}$ & $(7.74)^{* * *}$ & \\
\hline Multiplant & 0.891 & 0.890 & 0.897 & 1.854 & 1.974 \\
\hline (Plant level) & (1.29) & $(1.50)$ & $(1.36)$ & $(5.49)^{* * *}$ & $(5.04)^{* * *}$ \\
\hline Failed other plant & 0.541 & 0.540 & 0.541 & 0.826 & 0.671 \\
\hline (Plant level) & $(14.80)^{* * *}$ & $(15.79)^{* * *}$ & $(15.78)^{* * *}$ & $(4.33)^{* * *}$ & $(7.31)^{* * *}$ \\
\hline Labor productivity & 0.613 & 0.610 & 0.608 & 0.700 & 0.778 \\
\hline (Firm level) & $(13.85)^{* * *}$ & $(13.50)^{* * *}$ & $(13.42)^{* * *}$ & $(8.19)^{* * *}$ & $(4.37)^{* * *}$ \\
\hline Plant controls & Yes & Yes & Yes & Yes & Yes \\
\hline Firm controls & Yes & Yes & Yes & Yes & Yes \\
\hline Observation & 31,047 & 31,047 & 31,047 & 19,784 & 13,395 \\
\hline Wald Chi Square & 11,996 & 12,314 & 12,641 & 6,875 & 4,864 \\
\hline Hausman test (p-value) & 0.002 & 0.001 & 0.002 & & \\
\hline \multirow[t]{2}{*}{ Linktest (hatsq) } & 0.010 & 0.007 & 0.007 & -0.001 & 0.021 \\
\hline & $(0.98)$ & $(0.90)$ & $(0.90)$ & $(0.18)$ & $(2.22)^{* *}$ \\
\hline
\end{tabular}

Notes: Estimations are stratified by industry and year. Industries are defined at the SNI92 2-digit level (22 industries). Standard errors in parentheses. $* * *, * * * *$ indicate significance at 1,5 and 10 percent levels, respectively. Only plants in firms with 50 employees or more are included. In column (v) plants within firms taken over by other domestic firms are excluded. 
Table 9

Foreign and domestic acquisition of all Swedish manufacturing plants.

Growth in employment as dependent variable.

\begin{tabular}{|c|c|c|c|c|c|c|}
\hline & (i) & (ii) & (iii) & (iv) & (v) & (vi) \\
\hline & IV 1 & IV 2 & IV 3 & $\begin{array}{l}\text { Matched } \\
\text { sample }\end{array}$ & $\begin{array}{l}\text { Matched } \\
\text { sample }\end{array}$ & $\begin{array}{l}\text { Matched } \\
\text { sample }\end{array}$ \\
\hline $\begin{array}{l}\text { Vertical acquired } \\
\text { Swedish MNE }\end{array}$ & $\begin{array}{l}0.088 \\
(1.90)^{* *}\end{array}$ & $\begin{array}{l}0.078 \\
(1.84)^{*}\end{array}$ & $\begin{array}{l}0.052 \\
(1.63)\end{array}$ & $\begin{array}{c}0.021 \\
(1.67)^{*}\end{array}$ & $\begin{array}{c}0.025 \\
(1.71)^{*}\end{array}$ & \\
\hline $\begin{array}{l}\text { Vertical acquired } \\
\text { Swedish exporter }\end{array}$ & $\begin{array}{c}0.112 \\
(2.49)^{* * *}\end{array}$ & $\begin{array}{l}0.124 \\
(2.63)^{* * *}\end{array}$ & $\begin{array}{c}0.117 \\
(2.62)^{* * *}\end{array}$ & $\begin{array}{c}0.049 \\
(2.20)^{* * *}\end{array}$ & $\begin{array}{l}0.046 \\
(1.97)^{* *}\end{array}$ & \\
\hline $\begin{array}{c}\text { Vertical acquired } \\
\text { Swedish domestic }\end{array}$ & $\begin{array}{l}0.066 \\
(1.49)\end{array}$ & $\begin{array}{l}0.068 \\
(1.69)^{*}\end{array}$ & $\begin{array}{l}0.023 \\
(1.27)\end{array}$ & $\begin{array}{l}0.011 \\
(1.03)\end{array}$ & $\begin{array}{l}0.014 \\
(1.10)\end{array}$ & \\
\hline $\begin{array}{l}\text { Horizontal acquired } \\
\text { Swedish MNE }\end{array}$ & $\begin{array}{r}-0.033 \\
(0.31) \\
\end{array}$ & $\begin{array}{l}-0.053 \\
(0.55) \\
\end{array}$ & $\begin{array}{l}0.009 \\
(0.14) \\
\end{array}$ & $\begin{array}{r}-0.002 \\
(0.04) \\
\end{array}$ & $\begin{array}{l}0.012 \\
(0.22)\end{array}$ & \\
\hline $\begin{array}{l}\text { Horizontal acquired } \\
\text { Swedish exporter }\end{array}$ & $\begin{array}{l}0.027 \\
(0.44) \\
\end{array}$ & $\begin{array}{l}0.023 \\
(0.11) \\
\end{array}$ & $\begin{array}{l}0.010 \\
(0.15)\end{array}$ & $\begin{array}{l}0.013 \\
(1.17)\end{array}$ & $\begin{array}{l}0.013 \\
(0.73)\end{array}$ & \\
\hline $\begin{array}{l}\text { Horizontal acquired } \\
\text { Swedish domestic }\end{array}$ & $\begin{array}{l}-0.048 \\
(1.55)\end{array}$ & $\begin{array}{l}-0.022 \\
(0.93)\end{array}$ & $\begin{array}{l}-0.013 \\
(0.54)\end{array}$ & $\begin{array}{l}-0.009 \\
(0.21)\end{array}$ & $\begin{array}{l}0.012 \\
(0.50)\end{array}$ & \\
\hline Domestic acquisition & 0.062 & 0.060 & 0.026 & 0.021 & & 0.038 \\
\hline & $(1.70)^{*}$ & (1.61) & $(0.63)$ & $(2.79)^{* * *}$ & & $(3.54)^{* * *}$ \\
\hline Multiplant & -0.079 & -0.080 & -0.080 & -0.090 & -0.091 & -0.110 \\
\hline (Plant level) & $(13.63)^{* * *}$ & $(12.98)^{* * *}$ & $(12.88)^{* * *}$ & $(12.35)^{* * *}$ & $(10.69)^{* * *}$ & $(8.92)^{* * *}$ \\
\hline Failed other plant & -0.010 & -0.010 & -0.010 & -0.018 & -0.005 & -0.024 \\
\hline (Plant level) & $(1.75)^{*}$ & $(1.88)^{*}$ & $(1.63)$ & $(2.18)^{* *}$ & $(0.50)$ & $(2.01)^{* *}$ \\
\hline Growth in Labor productivity & 0.018 & 0.019 & 0.018 & 0.014 & 0.019 & -0.015 \\
\hline (Firm level) & $(2.11)^{* *}$ & $(2.15)^{* *}$ & $(2.00)^{* *}$ & $(1.14)$ & $(1.25)$ & $(0.65)$ \\
\hline Plant controls & Yes & Yes & Yes & Yes & Yes & Yes \\
\hline Firm controls & Yes & Yes & Yes & Yes & Yes & Yes \\
\hline Observation & 23,730 & 23,730 & 23,730 & 16,128 & 13,399 & 9,394 \\
\hline Adjusted R-squared & 0.02 & 0.02 & 0.02 & 0.03 & 0.03 & 0.03 \\
\hline Hausman test (p-value) & 0.002 & 0.002 & 0.001 & & & \\
\hline
\end{tabular}

Notes: All regressions contain year and 2-digit industry dummies. Standard errors in parentheses. ***, **** indicate significance at 1, 5 and 10 percent levels, respectively. Only plants in firms with 50 employees or more are included. In column (v) plants within firms taken over by other domestic firms are excluded. 


\section{Appendix}

Table A1 Foreign acquisitions by sectors 1994-2002

\begin{tabular}{|c|c|c|c|c|c|c|}
\hline \multirow[t]{2}{*}{ Industry } & \multirow[t]{2}{*}{$\begin{array}{l}\text { Target } \\
\text { firms }\end{array}$} & \multirow[t]{2}{*}{$\begin{array}{l}\text { Number of } \\
\text { firms* }\end{array}$} & \multirow[t]{2}{*}{$\begin{array}{l}\text { Plants within } \\
\text { target firms }\end{array}$} & \multirow[t]{2}{*}{$\begin{array}{l}\text { Number of } \\
\text { plants* }\end{array}$} & \multicolumn{2}{|c|}{$\begin{array}{c}\text { Acquisition share } \\
\text { Percent }\end{array}$} \\
\hline & & & & & Firm & Plant \\
\hline Food, beverages and tobacco & 14 & 179 & 246 & 2,821 & 7.8 & 8.7 \\
\hline Textiles, apparel and leather & 6 & 59 & 16 & 159 & 10.2 & 10.1 \\
\hline Wood products & 19 & 196 & 60 & 1,469 & 9.7 & 4.1 \\
\hline Paper and pulp products & 14 & 83 & 22 & 345 & 16.9 & 6.4 \\
\hline Printing and publishing & 13 & 255 & 43 & 2,706 & 5.1 & 1.6 \\
\hline Chemicals & 30 & 117 & 75 & 876 & 25.6 & 8.6 \\
\hline Rubber and plastics & 14 & 110 & 34 & 379 & 12.7 & 9.0 \\
\hline Non-metallic products & 13 & 79 & 166 & 739 & 16.5 & 22.5 \\
\hline Basic metals & 15 & 63 & 27 & 180 & 23.8 & 15.0 \\
\hline Non-electrical machinery & 31 & 297 & 52 & 1,017 & 10.4 & 5.1 \\
\hline Electrical machinery & 46 & 354 & 167 & 1,563 & 13.0 & 10.7 \\
\hline Telecommunication & 12 & 118 & 18 & 513 & 10.2 & 3.5 \\
\hline Professional goods & 6 & 66 & 20 & 488 & 9.1 & 4.1 \\
\hline Motor vehicles & 17 & 75 & 24 & 298 & 22.7 & 8.1 \\
\hline Transport equipment & 23 & 119 & 36 & 384 & 19.3 & 9.4 \\
\hline and other manufacturing & 15 & 177 & 27 & 660 & 8.5 & 4.1 \\
\hline Total & 288 & 2,347 & 1,033 & 14,597 & 12.3 & 7.1 \\
\hline
\end{tabular}

Notes: *Unique number of firms and plants during the period in each sector. 
Table A2 Mean variable differences between acquired and non-acquired firms in the preacquisition period, matched sample.

\begin{tabular}{|c|c|c|c|}
\hline Plant variables & $\mathrm{T}=0$ & $\mathrm{~T}=-1$ & $\mathrm{~T}=-2$ \\
\hline Employment & $\begin{array}{c}20 \\
(1.83)^{*}\end{array}$ & $\begin{array}{c}33 \\
(2.88)^{* * *}\end{array}$ & $\begin{array}{c}49 \\
(3.67)^{* * *}\end{array}$ \\
\hline Age & $\begin{array}{c}-1.40 \\
(6.85)^{* * *}\end{array}$ & $\begin{array}{c}-0.7 \\
(3.49)^{* * *}\end{array}$ & $\begin{array}{c}-0.61 \\
(2.58)^{* * *}\end{array}$ \\
\hline Skill intensity & $\begin{array}{l}-0.10 \\
(1.55)\end{array}$ & $\begin{array}{l}-0.05 \\
(0.77)\end{array}$ & $\begin{array}{l}-0.19 \\
(2.21)^{* *}\end{array}$ \\
\hline Obs. Target/Non-target & $907 / 10,776$ & $808 / 10,387$ & $572 / 10,121$ \\
\hline Firm variables & $\mathrm{T}=0$ & $\mathrm{~T}=-1$ & $\mathrm{~T}=-2$ \\
\hline Employment & $\begin{array}{c}78 \\
(0.88)\end{array}$ & $\begin{array}{c}76 \\
(0.81)\end{array}$ & $\begin{array}{c}46 \\
(0.44)\end{array}$ \\
\hline Skill intensity & $\begin{array}{c}0.9 \\
(0.86)\end{array}$ & $\begin{array}{c}0.3 \\
(0.32)\end{array}$ & $\begin{array}{c}0.6 \\
(0.55)\end{array}$ \\
\hline $\mathrm{R} \& \mathrm{D}$ intensity & $\begin{array}{c}0.1 \\
(0.37)\end{array}$ & $\begin{array}{c}0.2 \\
(0.67)\end{array}$ & $\begin{array}{c}0.1 \\
(0.36)\end{array}$ \\
\hline $\begin{array}{c}\text { Capital-labor } \\
\text { Ratio }\end{array}$ & $\begin{array}{c}23.6 \\
(0.68)\end{array}$ & $\begin{array}{c}50.0 \\
(1.37)\end{array}$ & $\begin{array}{l}16.3 \\
(0.43)\end{array}$ \\
\hline Shipment & $\begin{array}{c}285 \\
(1.13)\end{array}$ & $\begin{array}{c}252 \\
(0.95)\end{array}$ & $\begin{array}{c}172 \\
(0.60)\end{array}$ \\
\hline Export intensity & $\begin{array}{c}4.3 \\
(1.84)^{*}\end{array}$ & $\begin{array}{c}4.3 \\
(1.82)^{*}\end{array}$ & $\begin{array}{c}2.2 \\
(0.87)\end{array}$ \\
\hline Productivity & $\begin{array}{c}5.57 \\
(0.32)\end{array}$ & $\begin{array}{c}25.4 \\
(1.52)\end{array}$ & $\begin{array}{c}31.2 \\
(1.82)^{*}\end{array}$ \\
\hline Obs. Target/Non-target & $207 / 2,372$ & $198 / 2,240$ & $168 / 2,114$ \\
\hline
\end{tabular}

Table A3 The share of total number of firm and plant acquired by foreign MNEs. Whole and matched sample

\begin{tabular}{|c|c|c|c|c|c|c|}
\hline & \multicolumn{6}{c|}{ Whole sample } \\
\hline & \multicolumn{2}{|c|}{ Swedish MNEs } & \multicolumn{2}{c|}{$\begin{array}{c}\text { Exporting } \\
\text { non-MNEs }\end{array}$} & \multicolumn{2}{c|}{$\begin{array}{c}\text { Non-Exporting } \\
\text { non-MNEs }\end{array}$} \\
\hline & Firms & Plants & Firms & Plants & Firms & Plants \\
\hline $1993-2002$ & 30.6 & 31.5 & 56.6 & 56.0 & 12.8 & 12.5 \\
\hline & \multicolumn{7}{|c|}{ Matched sample } \\
\hline & \multicolumn{7}{|c|}{ Swedish MNE } & \multicolumn{2}{c|}{ Exporter } & Non-Exporter \\
\hline & Firms & Plants & Firms & Plants & Firms & Plants \\
\hline $1993-2002$ & 29.6 & 30.3 & 57.5 & 57.0 & 12.9 & 12.7 \\
\hline
\end{tabular}


Table A4 Result of the random-effects version of clog-log model.

\begin{tabular}{|c|c|c|c|c|}
\hline & (i) & (ii) & (iii) & (iv) \\
\hline & IV 1 & IV 2 & IV 3 & $\begin{array}{c}\text { Matched } \\
\text { sample }\end{array}$ \\
Vertical acquired & 0.751 & 0.964 & 1.225 & 0.891 \\
Swedish MNE & $(1.71)^{*}$ & $(1.33)$ & $(0.41)$ & $(1.67)^{*}$ \\
Vertical acquired & 0.326 & 0.317 & 0.401 & 0.752 \\
Swedish exporter & $(3.87)^{* * *}$ & $(3.96)^{* * *}$ & $(3.53)^{* * *}$ & $(3.02)^{* * *}$ \\
Vertical acquired & 1.152 & 1.762 & 0.911 & 1.619 \\
Swedish domestic & $(0.29)$ & $(1.14)$ & $(0.34)$ & $(1.57)$ \\
Horizontal acquired & 1.023 & 1.072 & 1.385 & 1.253 \\
Swedish MNE & $(0.56)$ & $(0.51)$ & $(0.82)$ & $(0.37)$ \\
Horizontal acquired & 0.821 & 0.792 & 0.809 & 0.931 \\
Swedish exporter & $(2.17)^{* *}$ & $(2.21)^{* * *}$ & $(2.19)^{* * *}$ & $(2.02)^{* * *}$ \\
Horizontal acquired & 1.341 & 2.021 & 1.629 & 2.489 \\
Swedish domestic & $(0.49)$ & $(0.85)$ & $(0.91)$ & $(1.01)$ \\
& & & & \\
Domestic acquisition & 0.224 & 0.271 & 0.247 & 0.557 \\
& $(6.89)^{* * *}$ & $(7.03)^{* * *}$ & $(8.02)^{* * *}$ & $(6.17)^{* * *}$ \\
Plant controls & Yes & Yes & Yes & Yes \\
Firm controls & Yes & Yes & Yes & Yes \\
\hline Observation & 31,047 & 31,047 & 31,047 & 19,784 \\
Wald Chi Square & 7,892 & 8,119 & 8,163 & 6,227 \\
\hline
\end{tabular}

Notes:

Estimation in (i) replicates the specification in Table8, column (i)

Estimation in (ii) replicates the specification in Table 8, column (ii)

Estimation in (iii) replicates the specification in Table 8, column (iii)

Estimation in (iv) replicates the specification in Table 8, column (iv)

Plant and firm controls included but not reported to save space.

For the estimations in columns (i) to (iv) we cannot reject the assumption that random effects are jointly equal to zero. 